\title{
Peningkatan Kualitas Penghitungan Emisi Gas Rumah Kaca dari Sektor Pengelolaan Sampah dengan Metode IPCC 2006 (Studi Kasus: Kota Cilacap)
}

\author{
Mochammad Chaerul ${ }^{1}$, Arry Febrianto ${ }^{1}$, dan Haryo Satriyo Tomo ${ }^{1}$
}

1Program Studi Magister Teknik Lingkungan, Fakultas Teknik Sipil dan Lingkungan, Institut Teknologi Bandung; e-mail: m.chaerul@ftsl.itb.ac.id

\begin{abstract}
ABSTRAK
Gas rumah kaca (GRK) berpotensi diemisikan dari berbagai tahapan dalam pengelolaan sampah, termasuk dari tahap penanganan sampah di sumber, pengangkutan dan penimbunan sampah di tempat pemrosesan akhir (TPA). Di banyak negara, metode IPCC 2006 dipilih untuk memprediksi emisi GRK dari berbagai macam sector, termasuk dalam pengelolaan sampah. Di dalam metode IPCC 2006 terdapat tingkatan basis data (Tier) yang didasarkan atas sumber data yang digunakan dalam menghitung emisi GRK. Tier 1 merupakan tingkatan terendah dimana berbagai macam data default telah disediakan untuk perhitungan emisi GRK. Penelitian ini bertujuan mengetahui emisi GRK yang dihasilkan dari pengelolaan sampah di Kota Cilacap sebagai representasi Kota kecil di Indonesia menggunakan metode IPCC 2006 tetapi dengan kualitas yang lebih baik daripada Tier 1. Peningkatan kualitas penghitungan dilakukan dengan menyediakan berbagai macam data spesifik untuk Kota Cilacap, diantaranya data timbulan dan komposisi sampah melalui sampling dan analisis laboratorium untuk mendapatkan proporsi organik karbon yang dapat terdegradasi (DOC), fraksi DOC yang terasimilasi (DOC $\mathrm{C}_{\mathrm{f}}$ ), laju degradasi (Kd) dan fraksi metana (F). Dari perhitungan didapat bahwa prediksi total emisi GRK dari pengelolaan sampah di Kota Cilacap sebesar 4,58 $\mathrm{x}$ $10^{5}$ ton $\mathrm{CO}_{2}$-eq. dimana tahap tahap pengangkutan dan penimbunan sampah menjadi yang dominan. Nilai total emisi dari penimbunan sampah berselisih sekitar $50 \%$ lebih besar dibandingkan bila menggunakan data default Tier 1 . Hasil ini semakin memperkuat urgensi implementasi konsep 3R (Reduce Reuse dan Recycle) mulai di sumber yang memang telah diamanatkan oleh Undang-Undang No. 18 tahun 2008 tentang Pengelolaan Sampah.
\end{abstract}

Kata kunci: Gas rumah kaca, Pengelolaan sampah, Tier, IPCC 2006, Sampling, Analisis laboratorium

\begin{abstract}
Greenhouse gasses (GHG) are potentially emitted by various stages in municipal solid waste management (MSWM), including from stage of waste handling at source, transportation and landfilling at final disposal site. IPCC 2006 method is commonly chosen in many countries to predict GHG emission from various sectors including from MSWM. In the method, in order to calculate GHG emission the different level of basis data (Tier) used is identified. Tier 1 is the lowest level which uses various default data provided for the calculation. The study aims to calculate GHG emission generated by MSWM in Cilacap City as a representative of small city in Indonesia using IPCC 2006 by increasing the quality of basis data (Tier 1 improved). Improvement of the bases data was conducted by providing various specific data for Cilacap City, such as waste generation and composition by sampling procedure, and laboratory analysis to provide the data of proportion of degradable organic carbon (DOC), fraction of DOC assimilated ( $\mathrm{DOC}_{\mathrm{f}}$ ), degradation rate $\left(\mathrm{K}_{\mathrm{d}}\right)$, and methane fraction (F). The result shows that the prediction of total GHG emission from MSWM in Cilacap City was $4.58 \times 10^{5}$ ton $\mathrm{CO}_{2}$-eq. in which the GHG emission from the waste transportation and landfilling becomes dominant. Emission from landfilling is $50 \%$ bigger compared to these when the default data in Tier 1 was used. The result is strengthening the urgency of implementation of $3 \mathrm{R}$ concept starting from the waste sources that has already been mandated by the law of 19 year of 2008 on Waste Management.
\end{abstract}

Keywords: Waste greenhouse gases, Municipal solid waste management, Tier, IPCC 2006, Sampling, Laboratory analysis

Citation: Chaerul, M., Febrianto, A., Tomo, H. S. (2020). Peningkatan Kualitas Penghitungan Emisi Gas Rumah Kaca dari Sektor Pengelolaan Sampah dengan Metode IPCC 2006 (Studi Kasus: Kota Cilacap). Jurnal Ilmu Lingkungan, 18(1), 153-161, doi:10.14710/jil.18.1.153-161

\section{Pendahuluan}

Sebuah laporan dari bank dunia memperkirakan bahwa hampir 1,3 miliar ton sampah dihasilkan secara global setiap tahunnya. Pada tahun 2010, Asia menyumbang $41 \%$ emisi gas rumah kaca (GRK) dari sektor persampahan global (596 metrik ton karbon dioksida ekivalen atau $\mathrm{MtCO}_{2}$ eq.) (Govindan dan Agamuthu, 2014). Analisis emisi GRK dari suatu sistem pengelolaan sampah suatu wilayah telah banyak dilakukan, bukan hanya untuk kondisi negara yang telah maju, tetapi juga untuk kondisi negara yang sedang berkembang (Ayodele et al., 2018, 
Chaerul, M., Febrianto, A., Tomo, H. S. (2020). Peningkatan Kualitas Penghitungan Emisi Gas Rumah Kaca dari Sektor Pengelolaan Sampah dengan Metode IPCC 2006 (Studi Kasus: Kota Cilacap). Jurnal Ilmu Lingkungan, 18(1), 153-161, doi:10.14710/jil.18.1.153-161

Ramachandra et al., 2018, Korai et al., 2017 dan Friedrich dan Trois, 2016).

Berbagai macam tahapan pengelolaan sampah berpotensi mengemisikan GRK mulai dari penanganan sampah di sumber, pengumpulan dan pengangkutan, pengolahan, dan penimbunan sampah. Emisi GRK dari tahap pengumpulan dan pengangkutan sampah lebih dipengaruhi oleh jarak pemindahan sampah dari satu titik ke titik yang lain. Sedangkan emisi GRK dari penanganan sampah, termasuk penanganan sampah di sumber, pengolahan dan penimbunan sampah lebih dipengaruhi oleh karakteristik sampah yang ditangani, terutama yang berkaitan dengan proporsi sampah organik.

Sampah yang dihasilkan dapat terdekomposisi menjadi senyawa-senyawa yang dapat berbahaya bagi lingkungan seperti GRK. Jumlah gas rumah kaca yang meningkat dari waktu ke waktu dihasilkan oleh berbagai macam kegiatan, terutama yang dihasilkan dari aktivitas penimbunan (landfilling) sampah di lokasi tempat pemrosesan akhir sampah (TPA), khususnya gas $\mathrm{CH}_{4}$ (metana) (Tchobanoglous, 1993). Perkiraan emisi metana pada landfill didasarkan pada jumlah timbulan sampah regional, fraksi landfill, fraksi landfill yang diharapkan dapat terdegradasi secara anaerobik, jumlah karbon organik yang dapat terdegradasi pada setiap fraksi jenis tersebut dan fraksi metana dalam biogas. Secara umum data persampahan di banyak negara kurang komprehensif, keandalan data yang dipertanyakan dan variabilitas data tidak diukur dengan baik akibat asumsi steady state yang banyak digunakan (Bogner dan Matthews, 2003).

Salah satu metode kuantifikasi gas rumah kaca yang banyak digunakan yaitu IPCC 2006 (Intergovernmental Panel on Climate Change) dari PBB (Perserikatan Bangsa Bangsa). IPCC 2006 merupakan metode untuk memperkirakan inventarisasi suatu negara atau daerah untuk emisi antropogenik gas rumah kaca dari sumber hingga penyerapannya untuk berbagai sektor termasuk sektor limbah. Pedoman IPCC 2006 memberikan pilihan tingkatan Tier (tingkat kedetailan basis data) yang dapat digunakan untuk memprediksi emisi GRK. Terdapat 3 Tier yang diakomodir metode IPCC 2006, yaitu Tier 1 (menggunakan data default), Tier 2 (menggunakan sebagian data spesifik lokasi) dan Tier 3 (menggunakan semua data spesifik).

Saat ini, prediksi emisi GRK di berbagai kota di Indonesia masih menggunakan Tier 1, terutama yang berhubungan dengan keterbatasan data karakteristik sampah yang dihasilkan (Chaerul et al., 2016). Tujuan dari penelitian ini adalah menyediakan beberapa parameter spesifik dalam metode IPCC 2006 yang dibutuhkan untuk menghitung prediksi emisi gas rumah kaca dari sistem pengelolaan sampah di Kota Cilacap sebagai representasi Kota kecil di Indonesia sehingga dapat memperbaiki kualitas basis data Tier 1 (Tier 1 yang ditingkatkan).

\section{Metodologi}

Untuk meningkatkan tingkatan kedetailan basis data (Tier) dalam perhitungan emisi GRK yang menggunakan metode IPCC 2006 dari suatu sistem pengelolaan sampah membutuhkan beberapa data spesifik, diantaranya meliputi: jumlah sampah yang terolah, jarak dan konsumsi bahan bakar kendaraan pengangkutan sampah, timbulan dan karakteristik sampah yang ditimbun di TPA. Dengan menggunakan berbagai macam data lapangan dan analisis laboratorium diatas selanjutnya dilakukan perhitungan emisi GRK dengan menggunakan metode IPCC 2006. Hasil yang didapat dari penelitian ini selanjutnya dibandingkan dengan perhitungan yang sama tetapi dengan menggunakan Tier 1.

\subsection{Pengumpulan data lapangan}

Pengumpulan Sebenarnya berbagai macam penanganan sampah di sumber berpotensi mengemisikan GRK, akan tetapi di penelitian ini emisi GRK hanya dibatasi untuk proses pengomposan yang dilakukan. Berdasarkan data yang diperoleh melalui wawancara dengan Dinas Cipta Karya dan Tata Ruang (DCKTR) Kabupaten Cilacap diperoleh bahwa hanya 1 fasilitas pengomposan yang masih beroperasi. Kapasitas pengomposan didapatkan berdasarkan wawancara terhadap pengelola fasilitas.

Pengambilan data pengangkutan dari sistem pengelolaan sampah dilakukan dengan melacak rute truk sampah dan mewawancarai pengemudi truk tentang identitas kendaraan dan konsumsi bahan bakar solar. Pelacakan rute dilakukan dengan cara mengikuti truk sampah dengan panduan GPS (Global Positioning System) selama satu hari operasional. Pengambilan data primer dilakukan terhadap 7 truk sampah dengan rincian 2 truk arm-roll, 1 truk dengan operasional transfer depo, 3 truk dengan operasional transfer depo serta ke daerah layanan, dan 1 truk dengan operasional door to door ke jalan-jalan protokol.

Pengambilan data penimbunan sampah berupa jumlah sampah yang dibuang setiap harinya dari Kota Cilacap dilakukan dengan menggunakan jembatan timbang sebelum dan sesudah truk sampah memasuki TPA. Sebenarnya terdapat beberapa TPA yang digunakan untuk menampung semuruh sampah dari Kabupaten Cilacap, akan tetapi dalam penelitian ini dibatasi untuk sampah yang dihasilkan dari wilayah Kota Cilacap yang seluruhnya dibuang ke TPA Jeruklegi. Pengamatan tersebut dilakukan selama delapan hari berturut-turut.

\subsection{Analisis laboratorium}

Analisis laboratorium dilakukan untuk mengetahui karakterisasi sampah yang dihasilkan dan potensi produksi biogas berikut proporsi gas metananya. Preparasi sampel dilakukan dengan mengumpulkan sampel sampah dari sumber. Pembagian kategori sampah didasarkan pada 
penelitian yang dilakukan Govindan dan Agamuthu (2014). Pengumpulan sampel dibagi menjadi beberapa kategori berdasarkan jenis dan sumbernya. Sampah pasar dan kertas mewakili sampah organik dari sektor komersial, sampah taman mewakili sampah organik dari sektor non domestik, dan sampah dapur mewakili sampah organik dari sektor domestik.

Beberapa karakteristik sampah spesifik yang didapat melalui analisis laboratorium meliputi parameter DOC, DOC , laju degradasi $\left(\mathrm{K}_{\mathrm{d}}\right)$ dan fraksi metana (F). Karbon organik yang dapat didegradasi (DOC) merupakan karbon organik pada sampah yang dapat didekomposisi secara biokimia. DOC pada sampah dalam jumlah besar diperkirakan berdasarkan komposisi sampah dan dapat juga dihitung dari berat rata-rata dari karbon yang dapat didegradasi dari berbagai komponen pada sampah. DOC dinyatakan dalam fraksi berat karbon terhadap berat sampah. Tidak semua organik karbon yang dapat didegradasi akan terdegradasi atau degradasinya sangat lambat pada kondisi anaerobik pada TPA. Fraksi dari organik karbon yang dapat meluruh dan terdegradasi dikenal dengan DOC $_{f}$. Jumlah DOC yang meluruh dari TPA tidak dapat menjadi acuan dari perkiraan nilai DOC $_{f}$ Pada umumnya jumlah DOC yang hilang bersama air lindi pada TPA kurang dari 1 persen dan dapat diabaikan dalam perhitungan (IPCC, 2006).

Pengukuran DOC dilakukan dengan terlebih dahulu menentukan kadar organik karbon. Analisis dilakukan pada setiap kategori sampah dengan menggunakan metode refluks terbuka yang mengacu pada SMEWW 5220-C. Zat organik dalam sampel dioksidasi oleh larutan $\mathrm{K}_{2} \mathrm{Cr}_{2} \mathrm{O}_{7}$ dalam suasana asam dengan menggunakan asam sulfat. Kelebihan $\mathrm{K}_{2} \mathrm{Cr}_{2} \mathrm{O}_{7}$ dititrasi oleh larutan ferro ammonium sulfat (FAS) dengan indikator ferroin. Pengukuran DOC dilakukan pada setiap kategori sampah dengan cara hidrolisis dengan $70 \%$ asam sulfat $(11,5 \mathrm{M})$ pada suhu 100 $105^{\circ} \mathrm{C}$ selama 5-6 jam berdasarkan penelitian yang telah dilakukan oleh Kolar et al. (2013).

Pengukuran $\mathrm{DOC}_{\mathrm{f}}$ dilakukan dengan pengukuran suhu zona anaerobik dari sampah berdasarkan penelitian yang dilakukan Hanson (2010) yang disimulasikan menggunakan tabung reaktor (Gambar 1a). Berbagai kategori sampah dimasukkan ke dalam tabung reaktor yang divakum dengan densitas dan komposisi yang disesuaikan dengan sampah Kota Cilacap. Nilai DOC $_{\mathrm{f}}$ dipengaruhi beberapa parameter proses, diantaranya temperatur proses. Pengamatan temperature di tabung reactor dilakukan selama 30 hari berturut-turut pada tiga titik yaitu atas, tengah dan bawah tabung.

Pengukuran laju degradasi $\left(\mathrm{K}_{\mathrm{d}}\right)$ dilakukan dengan menghitung selisih dari berat sampah setelah dan sebelum dimasukkan ke dalam tabung reaktor setelah 30 hari. Sedangkan pengukuran fraksi metana (F) dilakukan dengan menggunakan alat penampung gas metana (Gambar 1b) yang ditanam sedalam 2 meter di landfill. Gas pada landfill dipompa dan ditampung ke dalam balon penampung dengan pompa vakum. Komposisi gas pada balon penampung kemudian dianalisis dengan gas analyzer.

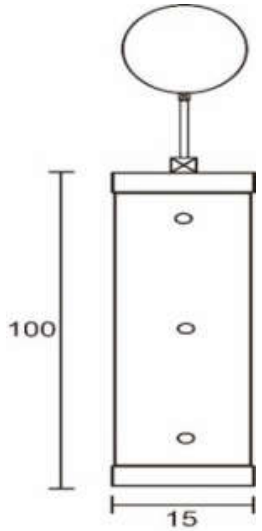

(a) Tabung Reaktor

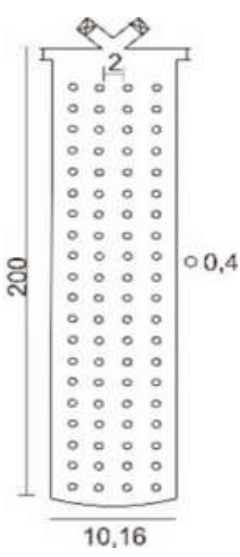

(b) Alat Penampung Gas di Landfill
Gambar 1. Reaktor Penelitian (dimensi dalam $\mathrm{cm}$ )

\subsection{Perhitungan dengan Metode IPCC 2006}

Metode Perhitungan emisi gas rumah kaca dengan metode IPCC 2006 untuk kasus Kota Cilacap dilakukan di tahap pengolahan sampah organik melalui proses pengomposan, pengangkutan sampah menuju TPA Jeruklegi, dan penimbunan sampah di TPA Jeruklegi. Terdapat 2 jenis emisi gas yang dihasilkan dari tahap pengolahan sampah sampah melalui pengomposan, yaitu $\mathrm{CH}_{4}$ dan $\mathrm{N}_{2} \mathrm{O}$.

Perhitungan emisi dari sektor pengolahan dilakukan dengan menggunakan persamaan (1) dan (2). Perhitungan untuk setiap emisi $\mathrm{CO}_{2}, \mathrm{CH}_{4}$ dan $\mathrm{N}_{2} \mathrm{O}$ dari sektor pengangkutan dilakukan dengan menggunakan persamaan (3). Sedangkan perhitungan emisi dari sektor penimbunan (landfilling) dilakukan dengan model WIP (waste in place) digunakan dengan model per tahun berdasarkan persamaan-persamaan (4) - (7) berikut.

dimana:

$$
\text { Emisi } \mathrm{CH}_{4(\mathrm{Gg})}=\left[\sum \mathrm{M}_{\mathrm{i}} \cdot \mathrm{EF}_{\mathrm{i}}\right] \cdot 10^{-3}-\mathrm{R}
$$

$\mathrm{M}_{\mathrm{i}}$ : massa sampah organik dengan proses $i(\mathrm{Gg})$

$\mathrm{EF}$ : faktor emisi dengan proses $i$ ( $\mathrm{g} \mathrm{CH}_{4} / \mathrm{kg}$ sampah)

$i$ : kompos atau $\mathrm{AD}$

$\mathrm{R}$ : jumlah recovery $\mathrm{CH}_{4}$ dalam inventarisasi tahunan ( $\left.\mathrm{Gg} \mathrm{CH}_{4}\right)$

$$
\text { Emisi } \mathrm{N}_{2} \mathrm{O}(\mathrm{Gg})=\sum \mathrm{M}_{\mathrm{i}} \cdot \mathrm{EF}_{\mathrm{i}} \cdot 10^{-3}
$$

dimana:

$\mathrm{M}_{\mathrm{i}}$ : massa sampah organik dengan proses $i(\mathrm{Gg})$

EF: faktor emisi dengan proses $i$ (g N $2 \mathrm{O} / \mathrm{kg} \mathrm{sampah}$ )

$i$ : kompos atau $\mathrm{AD}$

$$
\operatorname{Emisi}(\mathrm{Gg})=\sum\left[\text { Bahan bakara } . \mathrm{EF}_{\mathrm{a}}\right]
$$


dimana:

Bahan bakar $_{\text {a }}$ : jumlah bahan bakar yang dikonsumsi (liter)

$\mathrm{EF}_{\mathrm{a}}$

: faktor emisi $(\mathrm{kg} / \mathrm{T})$ ) untuk masingmasing $\mathrm{CO}_{2}, \mathrm{CH}_{4}$ dan $\mathrm{N}_{2} \mathrm{O}$

$\mathrm{a}$

: jenis bahan bakar (premium, solar, LPG, dll)

$$
\begin{aligned}
& \mathrm{DOC}=\sum\left(\mathrm{DOC}_{\mathrm{i}} \cdot \mathrm{W}_{\mathrm{i}}\right) \\
& \mathrm{DOC}_{\mathrm{f}}=0.014 \mathrm{~T}+0.28
\end{aligned}
$$

$\mathrm{DDOC}_{\mathrm{m}}=\mathrm{W} \cdot \mathrm{DOC} \cdot \mathrm{DOC}_{\mathrm{f}} \cdot \mathrm{MCF}$

Lo $=$ DDOC $_{m} \cdot$ F $\cdot 16 / 12$

dimana:

$\mathrm{DOC}_{\mathrm{i}} \quad$ : fraksi dari karbon degradasi pada sampah kategori $i$

W : fraksi dari sampah kategori $i(\mathrm{Gg})$

$\mathrm{DOC}_{\mathrm{f}} \quad$ : fraksi degradasi karbon organik

$\mathrm{T} \quad$ : temperatur dari zona anaerobik pada TPA $\left({ }^{\circ} \mathrm{C}\right)$

DDOC $_{m}$ : massa dari deposit DOC yang dapat dikomposkan (Gg)

W : total massa dari sampah yang terdapat di TPA (Gg)

DOC : degradable organic carbon (Gg C/Gg sampah)

$\mathrm{DOC}_{\mathrm{f}} \quad$ : fraksi dari DOC disimilasi

MCF : faktor koreksi metana (fraksi)

Lo : potensi gas metana yang dihasilkan, (Gg $\mathrm{CH}_{4}$ )

DDOC $_{m}$ : massa dari DOC yang dapat dikomposkan (Gg)

F $\quad$ : fraksi dari metana dari gas yang dihasilkan di TPA

16/12 : rasio berat molekul $\mathrm{CH}_{4} / \mathrm{C}$

\section{Hasil dan Pembahasan}

\subsection{Sistem pengolahan sampah Kota Cilacap}

Pada saat penelitian sebenarnya terdapat dua bank sampah di Kota Cilacap yaitu Bank Sampah Munggur Hijau dan Bank Sampah Mandiri, akan tetapi hanya Bank Sampah Munggur Hijau yang melakukan pengolahan sampah secara biologi yaitu dengan pengomposan dengan kapasitas sebesar $50 \mathrm{~kg} / \mathrm{bulan}$.

Dari tahap pengangkutan, berdasarkan hasil observasi dan wawancara didapatkan kebutuhan bahan bakar solar pada 17 truk sampah berkisar antara 0,4-0,9 liter per kilometer dengan total kebutuhan solar per minggu sebesar 2.730 liter dan total jarak tempuh sebesar $4.948 \mathrm{~km}$. Besarnya konsumsi bahan bakar disebabkan saat pengumpulan sampah mayoritas waktu truk berada dalam kondisi statis dengan kondisi mesin menyala. Jumlah emisi dari bahan bakar yang digunakan pada sektor pengangkutan bergantung pada beberapa faktor yaitu jenis sampah, area pengumpulan, jenis truk, jarak, dan perilaku mengemudi dari pengemudi (Chen dan Lo, 2015).

Penimbunan sampah yang dihasilkan dari Kota Cilacap dilakukan ke TPA Jeruklegi dengan menggunakan armada yang dikelola oleh DCKTR dan perusahaan-perusahaan besar yang ada di Cilacap. Jumlah rata-rata sampah yang diangkut ke TPA Jeruklegi pada tahun 2015 sebesar 72,42 ton/hari dengan rata-rata truk yang masuk sebanyak 20 truk/hari. Rata-rata ritasi per hari dari truk yang masuk sebesar 31 ritasi per hari atau 1,6 ritasi per truk dengan berat sampah yang terangkut sebesar 2,34 ton/ritasi.

\subsection{Nilai DOC (Degradable Organic Carbon)}

Perhitungan nilai DOC dilakukan berdasarkan persamaan 4. Tabel 1 memperlihatkan nilai DOC yang didapat berdasarkan analisis di laboratorium untuk setiap kategori sampah. Nilai DOC di sumber pada setiap kategori menunjukkan nilai yang lebih besar dibandingkan ketika di TPA. Hal tersebut menunjukkan bahwa komposisi memiliki pengaruh yang besar terhadap nilai DOC dari sampah (Thompson et al., 2009). Besarnya nilai DOC di sumber sampah dibandingkan di TPA mengindikasikan bahwa potensi degradasi sampah organik di masing-masing sumber lebih besar dibandingkan ketika di TPA. Dengan demikian, diperlukan pengangkutan secara cepat agar penanganan sampah bisa terlokalisasi sehingga lingkungan sekitar sumber sampah tidak tercemar. Perubahan komposisi sampah yang terjadi antara sumber dan pengangkutan disebabkan oleh perbedaan komposisi ketika sampah telah tercampur di TPS, sedangkan perubahan komposisi sampah yang terjadi pada proses pengangkutan dan di TPA disebabkan oleh perbedaan kontribusi setiap sumber sampah terhadap total sampah yang masuk ke TPA Jeruklegi.

\begin{tabular}{|c|c|c|c|c|c|c|}
\hline Kategori sampah & Kadar DOC & $\begin{array}{c}\text { Fraksi } \\
\text { komposisi di } \\
\text { sumber }\end{array}$ & $\begin{array}{l}\text { Fraksi komposisi } \\
\text { pengangkutan }\end{array}$ & $\begin{array}{c}\text { Fraksi komposisi } \\
\text { di TPA }\end{array}$ & $\begin{array}{l}\text { Nilai DOC } \\
\text { di sumber }\end{array}$ & $\begin{array}{c}\text { Nilai DOC di } \\
\text { TPA }\end{array}$ \\
\hline Sampah pasar & 0,56 & 0,64 & 0,42 & 0,06 & 0,36 & 0,03 \\
\hline Sampah dapur & 0,63 & 0,56 & 0,42 & 0,46 & 0,35 & 0,29 \\
\hline Sampah taman & 0,59 & 0,69 & 0,40 & 0,14 & 0,41 & 0,08 \\
\hline Kertas & 0,57 & 0,41 & 0,03 & 0,14 & 0,23 & 0,08 \\
\hline \multicolumn{6}{|c|}{ Total $\sum$ DOC bulk waste } & 0,48 \\
\hline
\end{tabular}

Tabel 1. Nilai DOC sampah Kota Cilacap 


\subsection{Nilai DOC $_{f}$ (Fraksi Degradable Organic Carbon) dan $K_{d}$ (Laju Degradasi)}

Penentuan nilai DOC $_{f}$ dilakukan dengan dua pendekatan yaitu berdasarkan simulasi penentuan temperatur zona anaerobik pada tabung reaktor dan berdasarkan gas metana yang dihasilkan dari tabung reaktor dan alat penampung gas di TPA. Penentuan DOC $_{f}$ berdasarkan simulasi penentuan temperatur zona anaerobik pada tabung reaktor dilakukan dengan perhitungan berdasarkan persamaan 5 . Menurut Hanson et al. (2010) temperatur optimum untuk produksi gas dari dekomposisi sampah ada dalam rentang suhu antara $34-45^{\circ} \mathrm{C}$. Dengan menghitung rata-rata suhu tabung kemudian mengambil nilai tengah dari rekomendasi temperatur sebesar $39^{\circ} \mathrm{C}$ didapatkan suhu terkoreksi. Penentuan nilai $K_{d}$ dan DOC dengan simulasi temperatur zona anaerobik dapat dilihat pada Tabel 2.

Tabel tersebut menunjukkan perbedaan hasil perhitungan antara $\mathrm{DOC}_{\mathrm{f}}, \mathrm{DOC}_{\mathrm{f}}$ terkoreksi, data standar IPCC dan data standar nasional Swedia menurut Borjesson et al. (2009). Perbedaan tersebut dapat dipengaruhi oleh temperatur rata-rata dari daerah penelitian (Yesiller et al., 2011). Dari hasil perhitungan terhadap 5 kategori sampah, tidak ada perbedaan yang berarti yaitu hanya 0,01 dari nilai DOC $_{f}$ pada setiap kategori sampah. Hal tersebut menunjukkan bahwa perbedaan jenis sampah tidak menimbulkan perbedaan pada temperatur dari zona anaerobik. Dengan demikian, dapat disimpulkan bahwa nilai $\mathrm{DOC}_{\mathrm{f}}$ untuk setiap kategori sampah dapat digeneralisasi menjadi satu nilai.

Penentuan DOC $_{\mathrm{f}}$ berdasarkan gas metana yang dihasilkan dari tabung reaktor dilakukan pada tabung bulk waste dan sampah pasar. Hal tersebut dikarenakan pada penentuan $\mathrm{K}_{\mathrm{d}}$ hanya tabung bulk waste dan sampah pasar yang menghasilkan gas secara signifikan. Nilai $K_{d}$ tertinggi dari penguraian sampah diketahui 0,19 setara dengan 3 tahun waktu paruhnya. Nilai tersebut diasosiasikan dengan kondisi kelembaban yang tinggi dan jenis sampah yang cepat terdegradasi seperti sampah makanan. Nilai $K_{d}$ terendah diketahui sebesar 0,02 setara dengan 35 tahun waktu paruhnya. Nilai tersebut diasosiasikan dengan kondisi kelembaban yang rendah dan jenis sampah yang terdegradasi secara perlahan seperti kayu-kayuan atau kertas (IPCC, 2006). Nilai Kd yang didapat akan berpengaruh terhadap waktu optimal yang dibutuhkan sampah untuk terdekomposisi. Perhitungan dilakukan dengan subtitusi balik terhadap persamaan 6 dan persamaan 7. Nilai DOC yang digunakan berdasarkan kadar DOC yang terdapat pada Tabel 1. Nilai MCF yang digunakan sebesar 0,8 karena tabung tidak dalam kondisi anaerob sepenuhnya (karena tidak dilakukan vaccum dengan nitrogen sehingga masih memungkinkan adanya oksigen di reaktor) dan didasarkan pada standar IPCC 2006 untuk klasifikasi TPA unmanaged 157 deep (tinggi sampah $>5 \mathrm{~m}$ ). Perhitungan nilai $\mathrm{DOC}_{\mathrm{f}}$ dengan subtitusi balik dapat dilihat pada Tabel 3.

Pada penentuan nilai $\mathrm{DOC}_{\mathrm{f}}$ antara subtitusi balik dengan temperatur zona anaerobik pada tabung reaktor diketahui terdapat perbedaaan. Menurut Govindan dan Agamuthu (2014) rentang nilai $\mathrm{DOC}_{\mathrm{f}}$ yang direkomendasikan antara 0,42-0,98. Perbedaan tersebut dikarenakan waktu pengamatan terhadap gas yang ditimbulkan dari tabung yang relatif singkat sehingga masih ada DOC yang belum terurai menjadi gas. Selain itu, kondisi tabung tidak dalam kondisi anaerobik secara menyeluruh sehingga belum semua DOC terdegradasi menjadi metana. Oleh sebab itu, penentuan $\mathrm{DOC}_{f}$ lebih baik dilakukan dengan pendekatan temperatur pada zona anaerobik dengan pengukuran secara in-situ karena relatif lebih mudah dan hasil yang didapat sesuai dengan rentang yang direkomendasikan. Pada penentuan nilai $\mathrm{DOC}_{\mathrm{f}}$ di alat penampung gas didapatkan nilai $\mathrm{DOC}_{\mathrm{f}}$ sebesar 0,01 . Nilai tersebut lebih kecil dibandingkan hasil perhitungan potensi nilai DOC f pada tabung bulk waste (Tabel 2). Hal tersebut dipengaruhi oleh umur landfill yang masih muda yaitu sekitar 5 bulan sehingga belum semua DOC terdegradasi menjadi metana. Menurut Hanson et al. (2010) pembentukan gas metana terjadi dengan cepat selama beberapa tahun dan kemudian akan menyusut selama beberapa dekade.

\subsection{Emisi GRK pada tahap pengelolaan sampah}

Penentuan potensi emisi pada tahap pengolahan dilakukan dengan terlebih dahulu menentukan jenis pengolahan dan jumlah sampah yang diolah kemudian dihitung potensi emisinya berdasarkan persamaan 1 dan persamaan 2 . Perhitungan emisi tahap pengolahan sampah di Kota Cilacap untuk kondisi eksisting dan peningkatan kapasitas dapat dilihat pada Tabel 4.

Berdasarkan hasil observasi hanya satu bank sampah yang melakukan pengolahan biologi yaitu sebanyak $50 \mathrm{~kg} /$ bulan dengan persentase pengolahan sampah biologi terhadap potensi timbulan sampah organik yang dapat dikomposkan dari wilayah pelayanan sebesar 0,7 persen. Apabila diterapkan skenario optimis bahwa setiap RW di Kota Cilacap memiliki bank sampah yang melakukan pengolahan biologi sebesar 0,7 persen dari potensi timbulan sampah organik yang dapat dikomposkan dari wilayah pelayanan, maka potensi sampah yang diolah dengan pengolahan biologi di semua bank sampah Kota Cilacap sebanyak 139 ton/tahun. Angka tersebut dihitung dari potensi sampah yang dapat dikomposkan di Kota Cilacap sebesar 19.874 ton/tahun. Angka pengomposan sebesar 139 ton/ton ini relatif kecil bila mempertimbangkan proporsi sampah organik yang diprediksi dihasilkan dari Kota Cilacap, sehingga sebenarnya dapat lebih ditingkatkan dengan penyediaan fasilitas pengomposan di TPS 3R. 
Semakin besar sampah yang diolah di sumber akan mengurangi jumlah sampah yang harus diangkut ke TPA.

\subsection{Emisi GRK pada tahap pengangkutan sampah}

Potensi emisi pada tahap pengangkutan sampah ditentukan berdasarkan jumlah bahan bakar yang dikonsumsi truk sampah berdasarkan persamaan 3 .
Perhitungan emisi tahap pengangkutan sampah untuk kondisi eksisting dan peningkatan pelayanan pengangkutan di Kota Cilacap dapat dilihat pada Tabel 5. Jumlah sampah yang diangkut ke TPA Jeruklegi dan kebutuhan bahan bakar solar untuk pengangkutan sampah didasarkan atas data sekunder yang didapatkan dari penelitian terkait.

Tabel 2. Nilai $\mathrm{K}_{\mathrm{d}}$ dan $\mathrm{DOC}_{\mathrm{f}}$ berdasarkan temperatur zona anaerobik

\begin{tabular}{|c|c|c|c|c|c|c|c|c|}
\hline Jenis sampah & $\mathrm{T}$ tabung $\left({ }^{\circ} \mathrm{C}\right)$ & $K_{d}$ & $\mathrm{DOC}_{\mathrm{f}}$ & T rekomendasi $\left({ }^{\circ} \mathrm{C}\right)$ & T terkoreksia) $\left({ }^{\circ} \mathrm{C}\right)$ & DOC $_{\mathrm{f}}$ terkoreksi & $\left.\mathrm{DOC}_{\mathrm{f}} \mathrm{b}\right)$ & $\overline{\mathrm{DOC}_{\mathrm{f}} \mathrm{cl}}$ \\
\hline Bulk waste & 26,9 & 0,18 & 0,66 & & 38,07 & 0,83 & & \\
\hline Sampah pasar & 27,7 & 0,11 & 0,67 & & 39,27 & 0,81 & & \\
\hline Sampah dapur & 26,9 & 0,19 & 0,66 & 39 & 38,09 & 0,84 & 0,5 & 0,7 \\
\hline Sampah taman & 28,0 & 0,08 & 0,67 & & 39,67 & 0,84 & & \\
\hline Kertas & 28,2 & 0,02 & 0,67 & & 39,89 & 0,81 & & \\
\hline
\end{tabular}

Tabel 3. Nilai $\mathrm{DOC}_{\mathrm{f}}$ berdasarkan perhitungan subtitusi balik

\begin{tabular}{|c|c|c|c|c|c|c|c|c|}
\hline Isi tabung & $\mathrm{F} \mathrm{CH}_{4}(\mathrm{ppm})$ & Vol. gas (liter) & Massa $\left.\mathrm{CH}_{4} \mathrm{Lo}(\mathrm{g})^{\mathrm{a}}\right)$ & $\mathrm{DDOC}_{\mathrm{m}}(\mathrm{g})$ & $W(g)^{b)}$ & DOC & MCF & $\mathrm{DOC}_{\mathrm{f}}$ \\
\hline Bulk waste & 62 & 18,8 & $7,65 \times 10^{-4}$ & 9,25 & 9.800 & 0,48 & & 0,003 \\
\hline Sampah pasar & 84 & 18 & $9,92 \times 10^{-4}$ & 8,86 & 3.000 & 0,36 & 0,8 & 0,01 \\
\hline Sampah TPA & $36,8 \times 10^{4}$ & 80 & 19,3 & 39,36 & 9.724 & 0,48 & & 0,01 \\
\hline
\end{tabular}

a) Massa jenis metana 0,656 kg/m³ (Sychev, 1987), b) densitas sampah TPA (600 kg/m³)

Tabel 4. Emisi GRK dari kondisi eksisting dan peningkatan kapasitas pengolahan sampah di Kota Cilacap

\begin{tabular}{lcccccc}
\hline \multicolumn{1}{c}{ Skenario } & $\begin{array}{c}\text { W sampah } \\
(\mathrm{kg} / \mathrm{tahun})\end{array}$ & $\begin{array}{c}\text { Faktor emisi } \mathrm{CH}_{4}(\mathrm{~g} \\
\left.\mathrm{CH}_{4} / \mathrm{kg}\right)\end{array}$ & $\begin{array}{c}\text { Faktor emisi N} \mathrm{O}(\mathrm{g} \\
\left.\mathrm{N}_{2} \mathrm{O} / \mathrm{kg}\right)\end{array}$ & $\mathrm{R}$ & $\begin{array}{c}\text { Emisi } \mathrm{CH}_{4} \\
(\mathrm{~kg} / \mathrm{tahun})\end{array}$ & $\begin{array}{c}\text { Emisi } \mathrm{N}_{2} \mathrm{O} \\
(\mathrm{kg} / \mathrm{tahun})\end{array}$ \\
\hline Eksisting & 600 & \multirow{2}{*}{0,3} & 0 & 2,4 & 0,18 \\
Peningkatan kapasitas & 139.000 & & & 0,3 & 556 & 41,7 \\
\hline
\end{tabular}

Tabel 5. Emisi GRK dari kondisi eksisting dan peningkatan pelayanan pengangkutan sampah di Kota Cilacap

\begin{tabular}{|c|c|c|c|c|c|c|c|c|c|}
\hline Skenario & $\begin{array}{l}\text { Jumlah } \\
\text { truk } \\
\text { (unit) }\end{array}$ & $\begin{array}{c}\text { Konsumsi } \\
\text { bahan bakar } \\
\text { (Liter/tahun) }\end{array}$ & $\begin{array}{l}\text { Nilai kalor } \\
\text { bersih } \\
(\mathrm{TJ} / \mathrm{Gg})^{\mathrm{a})}\end{array}$ & $\begin{array}{l}\mathrm{EF} \mathrm{CO}_{2} \\
(\mathrm{~kg} / \mathrm{TJ})\end{array}$ & $\begin{array}{l}\mathrm{EF} \mathrm{CH}_{4} \\
(\mathrm{~kg} / \mathrm{TJ})\end{array}$ & $\begin{array}{l}\mathrm{EF} \mathrm{N}_{2} \mathrm{O} \\
(\mathrm{kg} / \mathrm{T} J)\end{array}$ & $\begin{array}{c}\text { Emisi } \mathrm{CO}_{2} \\
\text { (ton) }\end{array}$ & $\begin{array}{c}\mathrm{Emisi} \\
\mathrm{CH}_{4} \\
\text { (ton) } \\
\end{array}$ & $\begin{array}{l}\text { Emisi } \\
\mathrm{N}_{2} \mathrm{O} \\
\text { (ton) }\end{array}$ \\
\hline Eksisting & 17 & 142.350 & \multirow{2}{*}{43} & \multirow[b]{2}{*}{74.100} & \multirow[b]{2}{*}{3,9} & \multirow[b]{2}{*}{3,9} & $3,82 \times 10^{5}$ & 20,1 & 20,1 \\
\hline Tambahan & 13 & 108.856 & & & & & $2,92 \times 10^{5}$ & 15,4 & 15,4 \\
\hline Total & 30 & 251.206 & & & & & $6,74 \times 10^{10}$ & 35,5 & 35,5 \\
\hline
\end{tabular}

a) Densitas solar = 0,843 kg/L (Kementrian ESDM, 2016)

Berdasarkan Chaerul (2016), jumlah sampah yang terangkut ke TPA Jeruklegi sebesar 72,42 ton/hari atau sekitar 53,86\% dari total timbulan sampah per hari yaitu $134.461 \mathrm{~kg} /$ hari yang berasal 5 Kecamatan wilayah pelayanan dengan total penduduk 396.437 jiwa (timbulan sampah di sumber 0,34 $\mathrm{kg}$ /orang/hari). Untuk memenuhi 100\% kebutuhan pelayanan pengangkutan sampah di 5 Kecamatan tersebut terdapat 62,041 ton sampah yang tidak terangkut, sehingga dibutuhkan tambahan 26,5 ritasi atau 13 truk tambahan. Total konsumsi bahan bakar solar untuk 17 truk sebesar 2.730 liter/minggu atau sebesar 23 liter/truk/hari. Dengan demikian, kebutuhan bahan bakar solar untuk 13 truk tambahan sebesar 298 liter/hari atau sebanyak 108.856 liter/tahun. Penambahan 13 truk akan meningkatkan emisi $\mathrm{CO}_{2}$ sebesar $77 \%$.

\subsection{Emisi GRK pada tahap penimbunan sampah}

GRK dihasilkan dari tahap penimbunan sampah yang diidientifikasi di IPCC 2006 berupa gas metana. Perhitungan perkiraan emisi metana dilakukan terhadap tabung reaktor dan beban emisi metana dari TPA Jeruklegi. Perhitungan dilakukan dengan nilai DOC pada sumber (Tabel 1) dan nilai DOCf yang didasarkan pada temperatur zona anaerobik pada Tabel 2. Perkiraan emisi metana dari 5 tabung reaktor dengan metoda perhitungan IPCC 2006 dapat dilihat pada Tabel 6.

Tabel 6. Perkiraan emisi metana menggunakan tabung reaktor

\begin{tabular}{lccccccc}
\hline \multicolumn{1}{c}{ Jenis sampah } & W $(\mathrm{kg})$ & Nilai DOC & Nilai DOC & MCF & DDOC $_{\mathrm{m}}(\mathrm{kg})$ & $\mathrm{F}$ & $\begin{array}{c}\mathrm{Lo} / \mathrm{W} \\
(\mathrm{kg} / \mathrm{kg})\end{array}$ \\
\hline Bulk waste & 9,8 & 0,48 & 0,66 & & 2,48 & 0,12 \\
Sampah pasar & 3 & 0,36 & 0,67 & & 0,86 & 0,23 \\
Sampah dapur & 10,05 & 0,35 & 0,66 & 0,8 & 1,86 & 0,37 & 0,92 \\
Sampah taman & 3 & 0,41 & 0,67 & & 0,66 & 0,10 \\
Kertas & 3 & 0,23 & 0,67 & & 0,37 & 0,33 & 0,10 \\
\hline
\end{tabular}


Hasil perhitungan perkiraan emisi metana yang didapat memiliki nilai yang lebih besar dibandingkan emisi yang didapatkan dari percobaan tabung reaktor bulk waste dan sampah pasar (Tabel 3). Hal tersebut dikarenakan waktu pengamatan yang singkat dan kondisi pada tabung tidak anaerobik secara menyeluruh sehingga memengaruhi emisi yang didapat. Faktor emisi dari bulk waste (Lo/W) memiliki nilai yang paling besar karena nilai DOC pada bulk waste merupakan akumulasi dari sampah organik di TPA yang didominasi oleh sisa makanan dari sektor domestik.
Penentuan perkiraan emisi dari tahap penimbunan sampah Kota Cilacap di TPA Jeruklegi menggunakan metode perhitungan IPCC 2006 berdasarkan persamaan 6 dan persamaan 7. Terdapat 2 pendekatan dalam penghitungan emisi metana yang dihasilkan dari tahap penimbunan sampah, yaitu: Tier 1 yang didasarkan data default dari IPCC 2006 dan Peningkatan Tier 1 (Tier 1 improved) yang didasarkan data spesifik hasil pengukuran yang telah dilakukan pada penelitian ini. Perbandingan emisi gas metana dari kedua Tier tersebut dapat dilihat pada Tabel 7.

Tabel 7. Perbandingan emisi metana menggunakan Tier berbeda dari tahap penimbunan sampah dalam satu tahun di TPA Jeruklegi

\begin{tabular}{lcccccccc}
\hline Pendekatan & $\begin{array}{c}\text { Jumlah sam-pah W } \\
\text { (ton) }\end{array}$ & DOC & DOC & MCF & $\begin{array}{c}\text { DDOCm } \\
\text { (ton) }\end{array}$ & $\begin{array}{c}\text { F } \\
\text { (ton) }\end{array}$ & $\begin{array}{c}\text { Lo/W }_{4} \\
\text { (ton/ton) }\end{array}$ \\
\hline Tier 1 & 26.433 & 0,31 & 0,50 & \multirow{2}{*}{0,8} & 3.278 & 0,50 & 2.185 \\
Tier 1 Improved & & 0,48 & 0,66 & & 6.560 & 0,37 & 3.304 \\
\hline
\end{tabular}

Emisi metana dari Tier 1 improved menunjukan nilai $50 \%$ yang lebih besar dibandingkan emisi metana dari Tier 1. Hal ini disebabkan karena perbedaan nilai DOC, DOC $f$ dan fraksi metana dari analisis laboratorium untuk sampah dari Kota Cilacap yang menunjukkan nilai lebih besar daripada nilai default yang diberikan oleh IPCC 2006.

Nilai parameter-parameter diatas dipengaruhi oleh komposisi sampah yang merupakan sampah organik sehingga lebih banyak potensi organik karbon yang dapat terdekomposisi. Komposisi sampah di Kota Cilacap dapat dilihat pada Gambar 1. Iklim yang tropis dengan kelembaban yang tinggi berpengaruh terhadap aktivitas bakteri pendekomposisi sehingga fraksi dari organik karbon yang dapat terdegradasi lebih tinggi dibandingkan wilayah yang memiliki 4 musim.

Menurut Machado et al. (2009), negara berkembang dengan iklim tropis memiliki laju degradasi sampah dan pembentukan metana yang tinggi. Fraksi metana yang didapatkan pada penelitian ini lebih rendah dibandingkan standar dari IPCC. Hal tersebut disebabkan umur dari sampah yang masih muda dan zona pengambilan sampah masih dalam zona aerobik.

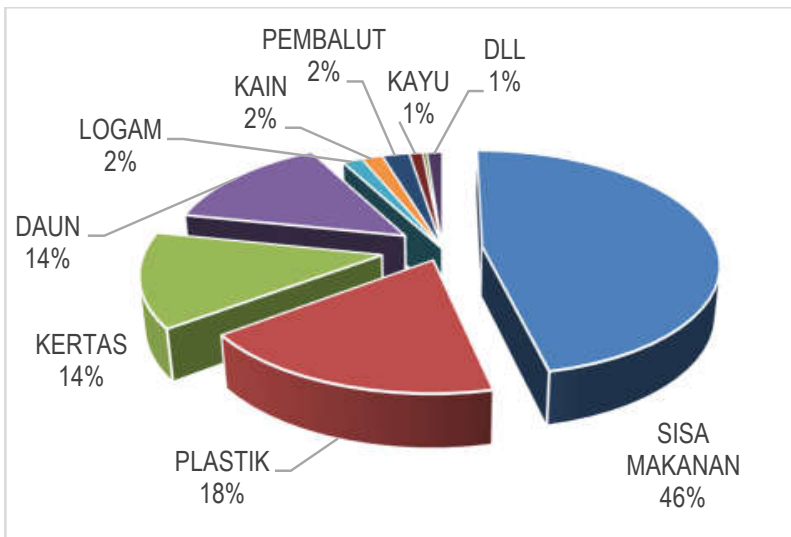

Gambar 1. Komposisi Sampah di Kota Cilacap

\subsection{Rekapitulasi Prediksi Emisi GRK dari Pengelolaan Sampah di Kota Cilacap}

Total prediksi emisi gas rumah kaca dari kondisi eksisting sistem pengelolaan sampah di Kota Cilacap dapat dilihat pada Tabel 8. Saat ini belum ada kegiatan pengolahan atau pemanfaatan sampah yang telah diangkut ke TPA. Kegiatan pemanfaatan sampah hanya dilakukan oleh sektor informal yang pada penelitian ini tidak dilakukan pendataan, sehingga diasumsikan semua sampah yang diangkut ke TPA Jeruklegi sama dengan jumlah sampah yang ditimbun.

Emisi GRK dari tahap pengolahan sampah sangat kecil dibandingkan tahapan lainnya karena kapasitas pengolahan dengan proses pengomposan yang masih sangat kecil. Sedangkan sumber dominan emisi GRK berasal dari tahap pengangkutan sampah. Selain dipengaruhi oleh jumlah sampah yang diangkut, emisi GRK juga dipengaruhi oleh rute pengangkutan dan kondisi kendaraan angkut sampah. Metode open dumping yang saat ini masih digunakan di TPA Jeruklegi menyumbang emisi GRK yang besar pula. Peningkatan metode operasional penimbunan menjadi controlled landfill atau sanitary landfill, termasuk apabila dilakukan pemanfaatan gas metana yang dihasilkan, diharapkan dapat mengurangi emisi GRK dari tahap penimbunan sampah.

Dengan mempertimbangkan jumlah sampah yang ditangani, dapat dihitung faktor emisi GRK dari setiap tahapan pengelolaan sampah yang dihasilkan Kota Cilacap (Tabel 8). Terlihat bahwa faktor emisi GRK yang terbesar berasal dari tahap pengangkutan sampah, diikuti tahap penimbunan dan yang terkecil berasal dari tahap pengomposan. Emisi dari tahap penimbunan sampah yang sebesar $6,94 \times 10^{4}$ ton $\mathrm{CO}_{2}$ eq./ton sampah bisa diperbandingkan dengan kondisi penimbunan sampah menggunakan metode sanitary landfill tanpa energy recovery di Kota Madrid, yang hanya sebesar $1.597 \mathrm{~kg} \mathrm{CO}_{2}$ eq./ton sampah (Perez et al., 2018). Selain karena metode penimbunan yang berbeda, komposisi sampah yang lebih banyak 
didominasi sampah organic dan karakteristik sampah organik yang lebih mudah terdegradasi mengakibatkan nilai emisi di Kota Cilacap ini menjadi jauh lebih besar. Faktor emisi GRK ini juga membuktikan bahwa pengolahan sampah di sumber bukan saja dapat menghemat biaya penanganan sampah selanjutnya karena jumlah sampah yang harus diangkut menjadi lebih sedikit, tetapi juga memiliki keunggulan dalam mengurangi emisi GRK.

Tabel 8. Total prediksi emisi GRK dari kondisi eksisting pengelolaan sampah di Kota Cilacap per tahun

\begin{tabular}{|c|c|c|c|c|c|}
\hline Tahapan pengelolaan & $\begin{array}{l}\text { Jumlah sampah } \\
\text { ditangani (ton) }\end{array}$ & $\begin{array}{l}\text { Emisi } \mathrm{CO}_{2} \\
\text { (ton) }\end{array}$ & $\begin{array}{l}\text { Emisi } \mathrm{CH}_{4} \\
\text { (ton) }\end{array}$ & $\begin{array}{l}\text { Emisi } \mathrm{N}_{2} \mathrm{O} \\
\text { (ton) }\end{array}$ & $\begin{array}{c}\text { Emisi } \\
\text { (ton } \mathrm{CO}_{2} \text {-eq) a) }\end{array}$ \\
\hline Pengolahan & 0,6 & - & $2,4 \times 10^{-3}$ & $0,18 \times 10^{-3}$ & 0,11 \\
\hline Pengangkutan & 26.433 & $3,82 \times 10^{5}$ & 20,1 & 20,1 & $3,89 \times 10^{5}$ \\
\hline Penimbunan & 26.433 & - & 3.304 & - & $6,94 \times 10^{4}$ \\
\hline \multicolumn{5}{|c|}{ Total } & $4,58 \times 10^{5}$ \\
\hline
\end{tabular}

a) $\mathrm{GWP} \mathrm{CH}_{4}=21, \mathrm{GWP} \mathrm{N} \mathrm{N}_{2} \mathrm{O}=310$ (World Bank, 2011)

\section{Kesimpulan}

Terdapat beberapa data spesifik yang dibutuhkan untuk meningkatkan kualitas hasil perhitungan emisi GRK dari sektor pengelolaan sampah dengan menggunakan metode IPCC 2006. Penelitian ini mencoba menyajikan berbagai macam data spesifik pengelolaan sampah untuk Kota Cilacap, terutama yang terkait dengan karakterisasi sampah melalui analisis laboratorium yang meliputi: Karbon organik yang dapat didegradasi (DOC), Fraksi dari organik karbon yang dapat meluruh dan terdegradasi ( $\mathrm{DOC}_{\mathrm{f}}$ ), laju degradasi $\left(\mathrm{K}_{\mathrm{d}}\right)$ dan fraksi metana (F). Data spesifik diatas akan mempengaruhi secara signifikan prediksi emisi GRK dari tahapan pengolahan dan penimbunan sampah. Dengan menggunakan data spesifik tersebut (Tier 1 Improved), didapat bahwa emisi GRK yang dihasilkan dari penimbunan sampah di Cilacap menjadi 50\% lebih besar daripada bila digunakan data default yang disediakan IPCC 2006 (Tier 1). Perhitungan yang dilakukan tidak dapat mencapai Tier 2 karena penelitian ini tidak dapat menyediakan semua data spesifik yang dibutuhkan.

Penelitian ini juga mendapatkan data faktor emisi dari tahapan pengolahan, pengangkutan dan penimbunan sampah dengan mempertimbangkan kapasitas sampah yang ditangani dari setiap tahapan tersebut. Untuk kasus Kota Cilacap, faktor emisi dari tahap pengangkutan dan penimbunan sampah menunjukan nilai yang jauh lebih besar dibandingkan faktor emisi dari pengolahan berupa pengomposan. Hal ini membuktikan bahwa pengolahan sampah di sumber akan mengemisikan GRK yang jauh lebih kecil dibandingkan bila harus diangkut dan sekedar ditimbun di TPA.

\section{DAFTAR PUSTAKA}

Ayodele, T.R. and M.A. Alao, A.S.O. Ogunjuyigbe. 2018. Recyclable Resources from Municipal Solid Waste: Assessment of Its Energy, Economic and Environmental Benefits in Nigeria. Resources, Conservation and Recycling. 134:165-173.

Bogner, J. and E. Matthews. 2003. Global Methane Emissions from Landfills: New Methodology and Annual Estimates 1980-1996. Global Biochemycal Cycle. 17(2):15-18.

Borjesson, G. and J. Samuelsson, J. Chanton, R. Adolfsson, B. Galle, B.H. Svensson. 2009. A National Landfill Methane
Budget for Sweden Based on Field Measurements, and An Evaluation of IPCC Models. Tellus B: Chemical and Physical Meteorology. 61(2):424-435.

Chaerul, M., 2016. Studi Spesifikasi Sampah di Kabupaten Cilacap. Laporan Pengembangan Proyek PT. Holcim dan DCKTR Kabupaten Cilacap. PT. Holcim.

Chaerul, M. dan G.G. Dirgantara, R. Akib. 2016. Prediction of Greenhouse Gasses Emission from Municipal solid Waste sector in Kendari City, Indonesia. Journal Manusia dan Lingkungan. 23(1):42-48.

Chen, Y. and S. Lo. 2015. Evaluation of Greenhouse Gas Emissions for Several Municipal Solid Waste Management Strategies. Journal of Cleaner Production. 113: 606-612

Friedrich, E. and C. Trois. 2016. Current and Future Greenhouse Gas (GHG) Emissions from the Management of Municipal Solid Waste in The eThekwini Municipality - South Africa. Journal of Cleaner Production. 112(5):4071-4083.

Govindan, S.S. and P. Agamuthu. 2014. Quantification of Landfill Methane Using Modified Intergovernmental Panel on Climate Change's Waste Model and Error Function Analysis. Waste Management \& Research. 32(10):1005-1014.

Hanson, J.L. and N. Yesiller, N.K. Oettle. 2010. Spatial and Temporal Temperature Distributions in Municipal Solid Waste Landfills. Journal of Environmental Engineering. 136(8):804-814.

IPCC, 2006. 2006 IPCC Guidelines for National Greenhouse Gas Inventories, Prepared by the National Greenhouse Gas Inventories Programme, Volume 5: Waste. Eggleston H.S., Buendia L., Miwa K., Ngara T. and Tanabe K. (eds). Published: IGES, Japan.

Kementrian ESDM, 2016. Standar dan Mutu (Spesifikasi) Bahan Bakar Minyak Jenis Solar 48. Jakarta.

Kolar, L. and R. Vachalova, J. Borova-batt, J. Vachal. 2013. A Method of Measuring the Degree of Organic Matter Degradability. Journal of Central European Agriculture. 14(3):969-977

Korai, M.S. and R.B. Mahar, M.A. Uqaili. 2017. The Feasibilitiy of Municipal Solid Waste for Energy Generation and Its Existing Management Practices in Pakistan. Renewable and Sustainable Energy Reviews. 72:338-353.

Machado, S.L. and M.F. Carvalho, J.P. Gourc, O.M. Vilar, J.C.F. Nascimento. 2009. Methane Generation in Tropical Landfills: Simplified Methods and Field Results. Waste Management. 29:153-161

Perez, J. and J.M. de Andres, J. Lumbreras, E. Rodriquez. 2018. Evaluating Carbon Footprint of Municipal Solid Waste Treatment: Methodological Proposal and 
Application to a Case Study. Journal of Cleaner Production. 205:419-431.

Ramachandra, T.V. and H.A. Bharath, G. Kulkarni, S.S. Han. 2018. Municipal Solid Waste: Generation, Compositition and GHG Emissions in Bangalore, India. Renewable and Sustainable Energy Reviews. 82(1):1122-1136.

Sychev, V.V., 1987. Thermodynamic Properties of Methane. Hemisphere Pub. Corp.

Tchobanoglous, G. and H. Theisen, S. Vigil. 1993. Integrated Solid Waste management. McGraw-Hill; First Edition edition (January 1, 1993).
Thompson, S. and J. Sawyer, R. Bonam, J.E. Valdivia. 2009. Building a Better Methane Generation Model: Validating Models with Methane Recovery Rates from 35 Canadian Landfills, Waste Management. 29:20852091.

World Bank, 2011. Greenhouse Gas Emissions Inventory Management Plan for Internal Business Operations 2010. Washington DC: The World Bank Group

Yesiller, N. and J.L. Hanson, H. Yoshida. 2011. Landfill Temperatures under Variable Decomposition Conditions. Advances in Geotechnical Engineering. 211:1055-1065. 